\title{
Preliminary analytical study of Ashvagandhadyarishta prepared from madhu and guda as sweetening agents
}

\author{
Research Article
}

\section{Rakshitha D $^{1 *}$, Sunil Mandal2 ${ }^{2}$, Gazala Hussain ${ }^{3}$, Vinay R Kadibagil ${ }^{4}$}

\author{
1,2. PG Scholar, 3, Associate Professor, 4. Professor, \\ Department of Rasashastra and Bhaishajya Kalpana,
}

Sri Dharmasthala Manjunatheshwara College of Ayurveda \& Hospital, Hassan, Karnataka, India.

\begin{abstract}
Introduction: Asava and arishta are medicinal preparations mentioned in Ayurvedic texts during which it undergoes a process of fermentation generating alcohol thus facilitating the extraction of the active principles contained in the drugs. Ashvagandhadyarishta is a type of arishta preparation where madhu (honey) is mentioned as madhura dravya (sweetening agent) in the formulation. So in this study an attempt is made to prepare Ashvagandhadyarishta in two batches by adding madhu as madhura dravya in one batch and guda (jaggery) as madhura dravya in another batch and to compare their organoleptic and analytical parameters. Materials and Methods: Study includes two batches of Ashvagandhadyarishta preparation followed the method as per Ayurvedic Formulary of India. Observations and Results: Analytical study of both the batches was done and their parameters were compared and analyzed including organoleptic features. Discussion: Both batches differ in the properties of final product as the sweetening agents used are different. Ashvagandhadyarishta containing guda as madhura dravya has greater values of analytical parameters comparatively, infers the influence of components present in guda. Conclusion: Change in the analytical and organoleptic characters were observed owing to the changes in the sweetening agents. Further research works has to be carried out to understand the clinical efficacy.
\end{abstract}

Key Words: Madhura dravya, Arishta, Ashvagandhadyarishta, Fermentation.

\section{Introduction}

Asava and arishta are medicinal preparations made by soaking the drugs either in powder form or in the form of kashaya (decoction) in a solution of sugar or jaggery for a specified period of time, during which it undergoes a process of fermentation generating alcohol thus facilitating the extraction of the active principles contained in the drugs (1). Ashvagandhadyarishta is a hydro-alcoholic preparation mentioned in Ayurveda Pharmaceutics. It is a type of arishta preparation which is a rasayana (rejuvenating) possess greater shelf- life compared to panchavidha kashaya kalpana where madhu (honey) is mentioned as madhura dravya (sweetening agent) in the formulation; indicated in murcha (syncope), apasmara (epilepsy), shosha (cachexia), unmada (psychosis), karshya (emaciation), arshas (piles), agnimandya (digestive impairment), vataroga (disease due to vata dosha) with the dose of 12 to $24 \mathrm{ml}$ (2). Usually guda (jaggery) is mentioned as madhura dravya in most of the arishta preparations but in ashvagandhadyarishta, madhu is mentioned where

\section{* Corresponding Author:}

\section{Rakshitha D}

PG Scholar,

Department of Rasashastra and Bhaishajya Kalpana,

Sri Dharmasthala Manjunatheshwara College of

Ayurveda \& Hospital, Hassan, Karnataka. India.

Email Id: rakshuammu2626@gmail.com both act as self preservative. So in this study an attempt is made to prepare ashvagandhadyarishta in two batches by adding madhu as madhura dravya in one batch and guda as madhura dravya in another batch and to compare their organoleptic and analytical parameters.

\section{Materials and Methods}

The method of preparation of ashvagandhadyarishta followed was Ayurvedic Formulary of India (3). Study includes two batches of ashvagandhadyarishta preparation. Batch 1 has ashvagandhadyarishta with madhu as madhura dravya and batch 2 has ashvagandhadyarishta with guda as madhura dravya. Ingredients were procured from local market of Hassan, Karnataka.

Table 1: Ingredients of Ashvagandhadyarishta

\begin{tabular}{|r|l|c|c|}
$\begin{array}{r}\text { Sl. } \\
\text { No. }\end{array}$ & \multicolumn{1}{|c|}{ Drugs } & Part used & Quantity \\
\hline 1 & $\begin{array}{l}\text { Ashvagandha (Withania } \\
\text { somnifera Dunal) }\end{array}$ & Root & $240 \mathrm{~g}$ \\
\hline 2 & $\begin{array}{l}\text { Musali (Asparagus } \\
\text { adseendens Roxb) }\end{array}$ & Root & $96 \mathrm{~g}$ \\
\hline 3 & $\begin{array}{l}\text { Manjishta (Rubia } \\
\text { cordifolia Linn) }\end{array}$ & Root & $48 \mathrm{~g}$ \\
\hline 4 & $\begin{array}{l}\text { Haritaki (Terminalia } \\
\text { chebula Retz) }\end{array}$ & Fruit pulp & $48 \mathrm{~g}$ \\
\hline 5 & $\begin{array}{l}\text { Haridra (Curcuma longa } \\
\text { Linn) }\end{array}$ & Rhizome \\
\hline $\begin{array}{l}\text { Daruharidra (Berberis } \\
\text { aristata Dc) }\end{array}$ & Stem & $48 \mathrm{~g}$ \\
\hline
\end{tabular}




\begin{tabular}{|c|c|c|}
\hline $7 \begin{array}{l}\text { Madhuka (Glycyrrhiza } \\
\text { glabra Linn) }\end{array}$ & Root & $48 \mathrm{~g}$ \\
\hline $8 \begin{array}{l}\text { Rasna (Alpinia } \\
\text { officinarum Hance) }\end{array}$ & Root & $48 \mathrm{~g}$ \\
\hline $\begin{array}{l}\text { Vidari (Pureria tuberosa } \\
\text { Dc) }\end{array}$ & Root & $48 \mathrm{~g}$ \\
\hline $\begin{array}{l}\text { Arjuna }(\text { Terminalia } \\
\text { arjuna } W \& A)\end{array}$ & Stem bark & $48 g$ \\
\hline $\begin{array}{l}\text { Musta (Cyperus } \\
\text { rotundus Linn) }\end{array}$ & Rhizome & $48 \mathrm{~g}$ \\
\hline $\begin{array}{l}\text { Trivrt (Operculina } \\
\text { turpethum L) }\end{array}$ & Root & $48 \mathrm{~g}$ \\
\hline $\begin{array}{l}\text { Swetha sariva } \\
\text { (Hemedismus indicus } \\
\text { R.Br) }\end{array}$ & Root & $38.4 \mathrm{~g}$ \\
\hline $\begin{array}{l}\text { Krishna sariva } \\
\text { (Ichnocarpus frutescens } \\
\text { R.Br) }\end{array}$ & Root & $38.4 \mathrm{~g}$ \\
\hline $\begin{array}{l}\text { Sweta chandana } \\
\text { (Santalum album Linn) }\end{array}$ & Heartwood & $38.4 \mathrm{~g}$ \\
\hline $\begin{array}{l}\text { Rakta chandana } \\
\text { (Pterocarpus santalinus } \\
\text { Linn) }\end{array}$ & Heartwood & $38.4 \mathrm{~g}$ \\
\hline $\begin{array}{l}\text { Vacha (Acorus calamus } \\
\text { Linn) }\end{array}$ & Rhizome & $38.4 \mathrm{~g}$ \\
\hline $\begin{array}{l}\text { Chitraka (Plumbago } \\
\text { zeylanica Linn) }\end{array}$ & Root & $38.4 \mathrm{~g}$ \\
\hline $\begin{array}{l}\text { Water taken } \\
\text { Reduced to }\end{array}$ & & $\begin{array}{l}9.8001 \\
1.2001\end{array}$ \\
\hline
\end{tabular}

Ingredients and their quantity were taken same for both the batches of ashvagandhadyarishta. Also prakshepaka dravya and its quantity were taken same for both the batches but instead of madhu, guda was taken in batch 2 for the preparation.

\section{Table 2: Prakshepaka dravya of} Ashvagandhadyarishta batch 1 and batch 2

\begin{tabular}{|c|l|c|c|}
\hline $\begin{array}{c}\text { Sl. } \\
\text { No. }\end{array}$ & \multicolumn{1}{|c|}{ Drugs } & Part used & Quantity \\
\hline 1 & Madhu & $1440 \mathrm{~g}$ \\
\hline 2 & $\begin{array}{l}\text { Dhataki (Woodfordia } \\
\text { fruticosa Salisb) }\end{array}$ & Flower & $76.8 \mathrm{~g}$ \\
\hline 3 & $\begin{array}{l}\text { Shunti (Zingiber } \\
\text { officinale) }\end{array}$ & Rhizome & $9.6 \mathrm{~g}$ \\
\hline 4 & $\begin{array}{l}\text { Maricha (Piper nigrum } \\
\text { Linn) }\end{array}$ & Fruit & $9.6 \mathrm{~g}$ \\
\hline 5 & $\begin{array}{l}\text { Pippali (Piper longum } \\
\text { Linn) }\end{array}$ & Fruit & $9.6 \mathrm{~g}$ \\
\hline 6 & $\begin{array}{l}\text { Twak (Cinnamomum } \\
\text { zeylanica Blume) }\end{array}$ & Stem bark & $19.2 \mathrm{~g}$ \\
\hline 7 & $\begin{array}{l}\text { Ela } \text { (Elettaria } \\
\text { cardamomum Maton) }\end{array}$ & Seed & $19.2 \mathrm{~g}$ \\
\hline 8 & $\begin{array}{l}\text { Patra } \text { (Cinnamomum } \\
\text { tamala) }\end{array}$ & Leaf & $19.2 \mathrm{~g}$ \\
\hline 9 & $\begin{array}{l}\text { Priyangu (Callicarpa } \\
\text { macrophylla Vahl) }\end{array}$ & Flower & $19.2 \mathrm{~g}$ \\
\hline 10 & $\begin{array}{l}\text { Nagakesara } \text { (Mesua } \\
\text { ferrea Linn) }\end{array}$ & Flower & $9.6 \mathrm{~g}$ \\
\hline
\end{tabular}

\section{Method of preparation (4):}

The drugs were coarsely powdered and prescribed amount of water was added and heated over moderate flame to prepare kashaya. After it was reduced to $/ 4^{\text {th }}$ part, the kashaya was filtered and strained through a cloth. To batch 1, madhu was added after the kashaya cooled down along with the

prakshepaka dravya and dhataki pushpa. To batch 2, guda was added when the kashaya was hot itself for easy dissolution, filtered and then transferred to fermentation vessel and kept in fermentation vessel and prakshepaka dravya and dhataki pushpa was added. The mouth of the vessel was covered with a lid and then it was examined for commencement of fermentation. The container was kept in a heap of paddy to maintain the constant temperature with the edges sealed. After a period of 20 days, the lid was removed and examined for the completion of fermentation that showed features viz., sunken prakshepaka dravya, cessation of effervescence and hissing sound and presence of strong alcoholic odor. Finally it was filtered and stored in a clean closed container.

Fig 1: Ingredients of Ashvagandhadyarishta

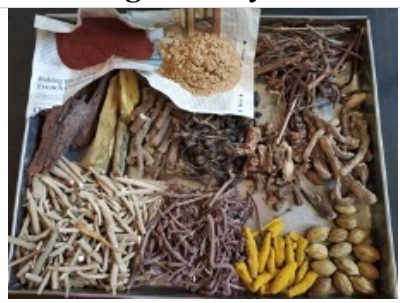

Fig 3: Dhupana dravya

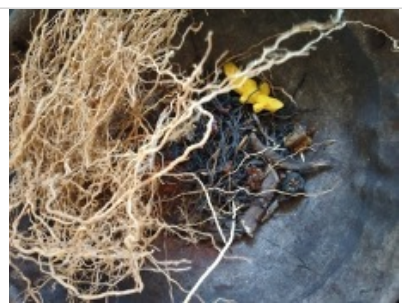

Fig 5: During preparation

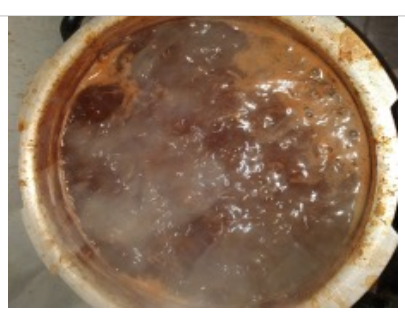

Fig 7: Final product

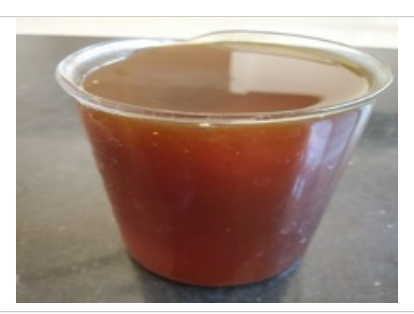

\section{Observations and Results}

Analytical study of both the batches was done by following procedures given in CCRAS protocol (5). Organoleptic and analytical parameters of both the batches were analyzed.
Fig 2: Prakshepaka dravya

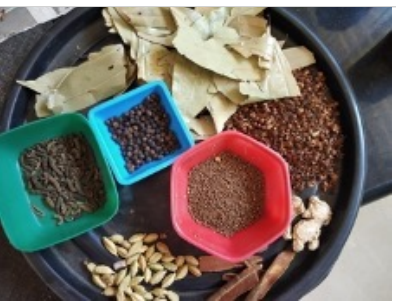

Fig 4: Dhataki pushpa

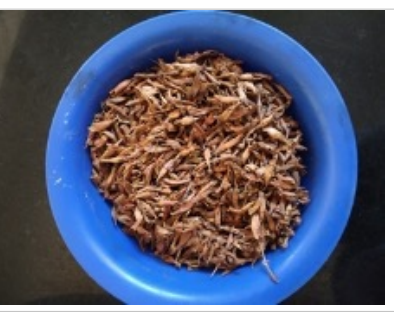

Fig 6: Kept for fermentation

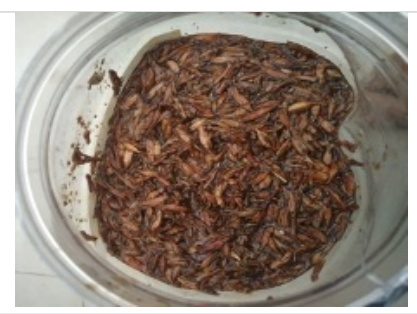


Table 3: Organoleptic parameters of both batches of Ashvagandhadyarishta

\begin{tabular}{|c|c|c|c|}
\hline $\begin{array}{c}\text { Sl. } \\
\text { No. }\end{array}$ & Parameters & Batch 1 & Batch 2 \\
\hline 1 & Appearance & $\begin{array}{c}\text { Liquid } \\
\text { consistency }\end{array}$ & $\begin{array}{c}\text { Thicker } \\
\text { consistency }\end{array}$ \\
\hline 2 & Color & $\begin{array}{c}\text { Brownish } \\
\text { Brownish }\end{array}$ \\
\hline 3 & Odor & $\begin{array}{c}\text { Mild alcoholic } \\
\text { odor } \\
\text { Kashaya } \\
\text { (astringent) } \\
\text { pradhana } \\
\text { katu (pungent) }\end{array}$ & $\begin{array}{c}\text { Strong alcoholic } \\
\text { and guda } \text { odor }\end{array}$ \\
$\begin{array}{c}\text { Madhura } \\
\text { (sweet) } \\
\text { pradhana } \\
\text { tikta (bitter) }\end{array}$ \\
\hline
\end{tabular}

Table 4: Analytical parameters of both batches of Ashvagandhadyarishta

\begin{tabular}{|c|c|c|c|}
\hline SI. No. & Parameters & Batch 1 & Batch 2 \\
\hline 1 & $\begin{array}{c}\mathrm{pH} \\
\text { Specific gravity } \\
\left(\mathrm{kg} / \mathrm{m}^{3}\right)\end{array}$ & 3.49 & 4.47 \\
\hline 2 & 1.1302 & 1.2252 \\
\hline 3 & $\begin{array}{c}\text { Total Suspended } \\
\text { Solids (TSS \%) }\end{array}$ & 35 & $>35$ \\
\hline 4 & Refractive index & 1.479 & 1.541 \\
\hline 5 & Viscosity (Pa.s) & 0.0461 & 0.1592 \\
\hline 6 & Alcohol (\%) & 8 & 10 \\
\hline
\end{tabular}

\section{Discussion}

Ashvagandhadyarishta is a known formulation indicated for murcha, apasmara, shosha, unmada, karshya, arshas, agnimandya, vataroga. Even though the method followed was same for both the batches, it differs in the properties of final product as the sweetening agents used were different. Madhu and guda are madhura (sweet) rasa pradhana but differs in their gunadikarma. Batch 1 is kashaya (astringent) pradhana katu (pungent) due to the katu (pungent) vipaka of madhu where batch 2 is madhura predominant in taste because of madhura vipaka of guda (6). Batch 2 is thicker in consistency due to snigdha (unctuous) guna of guda (7).

Batch 1 is more acidic due to madhu as it has $\mathrm{pH}$ of 4 while jaggery has $\mathrm{pH}$ of 6 . Specific gravity, viscosity and total suspended solids are more for batch 2 containing guda due to the presence of more components in jaggery (8). Also the particle size present in jaggery has significantly affected on the chemical properties of it (9). Alcoholic percentage is also more in batch 2 as it is rich in sugar percentage; that has undergone more fermentation leading to the release of more alcoholic production(10).

\section{Conclusion}

Ashvagandhadyarishta is a hydro- alcoholic preparation mentioned in Ayurveda Pharmaceutics which possesses greater shelf- life compared to panchavidha kashaya kalpana. Method of preparation is also easy with the easy availability of drugs. This trial carried out to design ashvagandhadyarishta by altering sweetening agents showed difference in both analytical and organoleptic parameters owing to the properties of sweetening agents. Guda is a concentrated form of cane juice hence components present in guda lead to increase in analytical parameters such as viscosity, total suspended solids, etc. Gunadikarma also changes owing to the change in sweetening agents. This has to be confirmed by coming out clinical study which opens the path for taking clinical research on it.

\section{Reference}

1. Government of India Ministry of Health \& Family Welfare. The Ayurvedic Formulary of India. 2nd ed: part 1. The Controller of Publications Civil Lines: New Delhi; 2003: 3.

2. Ambikadatta Shastry Kaviraj. Bhaishajya Ratnavali. Murcharoga Chikitsa Prakaranam, verse 15- 21. Chawkhamba Publications: Varanasi; 2001: 356.

3. Government of India Ministry of Health \& Family Welfare. The Ayurvedic Formulary of India. $2^{\text {nd }}$ ed: part 1. The Controller of Publications Civil Lines: New Delhi; 2003: 9

4. Ambikadatta Shastry Kaviraj. Bhaishajya Ratnavali. Murcharoga Chikitsa Prakaranam, verse 15- 21. Chawkhamba Publications: Varanasi; 2001: 355.

5. CCRAS, Laboratory Guide for the Analysis of Ayurveda and Siddha Formulations. 1st ed: CCRAS Department of AYUSH, Ministry of Health and Family Welfare; New Delhi: 2009.

6. Rajesh CK, Shajahan MA, Shahul Hameed A. Ayurvedic Review On Guda (Jaggery). AyurpharmInternational Journal of Ayurveda and Allied Sciences. 2016; 5(5): 69.http://www.ayurpharm.com/ index.php/archives/category/60-volume-5-issue5? download=174:review-article-ayurvedic-review-onguda-jaggery-rajesh-ck-shajahan-mashahul-hameeda.

7. Rajesh CK, Shajahan MA, Shahul Hameed A. Ayurvedic Review On Guda (Jaggery). AyurpharmInternational Journal of Ayurveda and Allied Sciences. $2016 ; 5(5): 71$. ht tp:// www.ayurpharm.com/index.php/archives/category/ 60-volume-5-issue5?download=174:review-articleayurvedic-review-on-guda-jaggery-rajesh-ckshajahan-mashahul-hameed-a

8. Nath A, Dutta D, Kumar Pawan, Singh JP. Review on recent advances in value addition of Jaggery based products. Food processing and technology. 2015; 6: 2-4. https://www.longdom.org/open-access/ review-on-recent-advances-in-value-addition-ofjaggerybased-products-2157-7110-1000440.pdf

9. Unde P.A., Adagale P.V., Imran Hashmi Syed, Raheem Abdul. Effect of different particle sizes of Jaggery powder on storability. World Journal of Agricultural Sciences. 2011; 7(2): 157-160. https:// citeseerx.ist.psu.edu/viewdoc/download? doi $=10.1 .1 .415 .479 \&$ rep $=$ rep1\& type $=$ pdf

10. Malakar Santanu, et al. Biotechnological interventions in beverage production. Science Direct. 2020; 19: 1-37. https://www.sciencedirect.com/ science/article/pii/B9780128166789000011 